\title{
Roman Woodworking
}





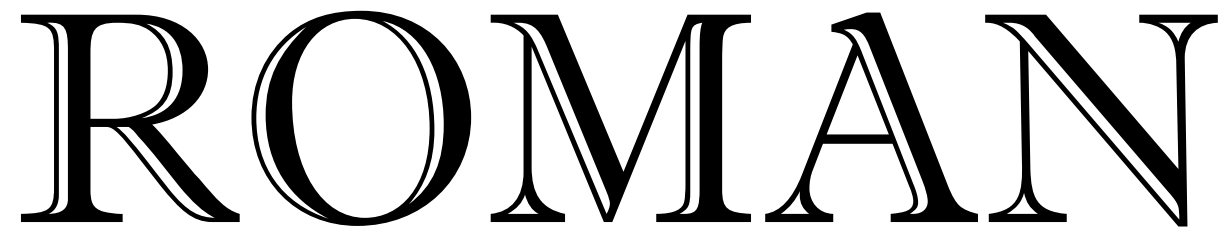

Woodworking

Roger B. Ulrich 
Published with assistance from the office of the Dean of the Faculty, Dartmouth College.

Copyright $\odot 2007$ by Yale University.

All rights reserved.

This book may not be reproduced, in whole or in part, including illustrations, in any form (beyond that copying permitted by Sections 107 and 108 of the U.S.

Copyright Law and except by reviewers for the public press), without written permission from the publishers.

Set in Quadraat by Tseng Information Systems, Inc., Durham, North Carolina. Designed by Gregg Chase.

Printed in the United States of America by Sheridan Books, Ann Arbor, Michigan.

Library of Congress Cataloging-in-Publication Data

Ulrich, Roger Bradley.

Roman woodworking / Roger B. Ulrich

p. $\mathrm{cm}$.

Includes bibliographical references and index.

ISBN-I3: 978-0-300-I034I-o (alk. paper)

ISBN-IO: 0-300-I034I-7 (alk. paper)

I. Building, Wooden-Rome. 2. Carpentry-History-To 1500.

3. Woodwork-Rome. 4. Rome-Antiquities. I. Title.

THIIII.U47 2006

$684^{\prime} .080937-\mathrm{dc} 22 \quad 2006003784$

A catalogue record for this book is available from the British Library.

The paper in this book meets the guidelines for permanence and durability of the Committee on Production Guidelines for Book Longevity of the Council on Library Resources.

I0 98765432 I 
For Imogen 
